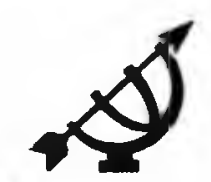

\title{
Property rights and hierarchies of power: a critical evaluation of land-reform policy in South Africa*
}

\author{
André van der Walt \\ Department of Private Law \\ University of South Africa \\ PRETORIA \\ E-mail: vdwalaj@alpha.unisa.ac.za
}

\begin{abstract}
Property rights and hierarchies of power: a critical evaluation of land reform policy in South Africa
\end{abstract}

The programme of land reform lows introduced in South Africa since 1991 is often seen and discussed as nothing more than a highly technical, black-letter aspect of South African law. In this article, the author directs attention to the policies that underly the land reform lows, and discusses the transformative potential and effect of land reform laws in view of these policies. The main question is whether the land reform programme has succeeded in breaking away from or undermining the hierarchies of power that were inherent in traditional common-law property relationships and, particularly, in the politically sanctioned and statutorily entrenched system of apartheid land low. Through the analysis of the most important land reform laws the author concludes that the land reform programme is only partially successful in this regard, since many of the new laws still uphold

- Earlier drafts of this article were presented and discussed at a seminar organised by the Lincoln Institute of Land Policy, Cambridge, Massachusetts, on 6 April 1998, and at a meeting of the Comparative Studies Group, Duke University, Durham, North Carolina, on 14 April 1998 Thanks to the organisers of and participants in those discussions for valuable discussions and feedback; to Karen Prinsloo and Marjan Gerbrands for research assistance, and to Greg Alexander, Henk Botha, Johan Erasmus, Riel Franzsen, Danie Goosen, Duncan Kennedy, Karl Klare, Wessel le Roux, Joe Singer, Laura Underkuffler-Freund, Karin van Marle, Lucy Williams and Joan Youngman for discussions and helpful comments. The errors are all my own 
or entrench the underlying hierarchies of power that characterised apartheid land law.

\section{Introduction}

\subsection{Land reform and land reform policy}

Ever since the former National Party government introduced the first, hesitant land reforms in 1991, land policy choices involved in the process of land reform and their effects on the existing system of property rights have been a central transformation issue in the South African legal and political debate. This debate was and still is not always clear on policy direction - in fact, in many instances the policy decisions behind the reforms that are introduced are unclear and uncertain, and in some cases they are or seem inconsistent. In this article I attempt to identify, as far as possible, policy decisions with regard to the kind of property rights that are privileged by the land reform policies, programmes and legislation that have been introduced to date. These policy choices have important and often essential implications not only for the efficacy of the process of land reform, but also for the course and the effects of transformation in the legal, social, economic and political spheres in general.

The policy choices I have in mind are of a particular kind. They involve, generally speaking, choices that privilege a certain kind of property rights over others, by creating, reinforcing, distributing or redistributing these property rights rather than others. Judged against the urgency of other policy issues involved in land reform this kind of policy choice may seem unimportant, but in fact it indicates a deeper and often unconscious policy choice for (the continuation of a specific kind of legal, social, economic and political system. My point of departure is inspired by Realist thinking, and my aim is therefore to judge the law in terms of its effects: to identify the choices that can be inferred from land reform policies, programmes and legislation, and to indicate the possible implications of these choices for the continuation and entrenchment of existing power relations. $\mathrm{My}$ analysis concentrates on the implications of reform policy for property theory and legal theory, and although I do not aim to identify or to comment on all the implications that these choices might have for other practical considerations such as the implementation of a land tax regime or for the functioning of local government, I think that my analysis could provide a basis for further investigation into those areas as well.

There are several reasons for celebrating Johan van der Vyver's contribution to South African legal culture with an article like this. His colleagues and students remember - no doubt with varying degrees of fondness - the vigour with which he opposed and criticised the injustices of apartheid (including apartheid land 
law) when it was still unusual and unpopular to do so. He pointed out the (then still revolutionary but now widely accepted) fact that the seemingly neutral, technical mechanics of law have fundamental social, political and legal implications that need to be exposed and subjected to critical analysis, and that private-law specialists cannot afford to retreat into the ivory tower of "pure" civil law and leave the rest of the field open to the whims and fancies of politicians and technocrats. As an exercise in the socio-political and legal-theoretical evaluation of policy frameworks behind the technicalities of land law, this article recognises Johan van der Vyver's lasting influence on the tradition of critical legal theory in South Africa. At the same time, this article is also a sign of appreciation for his equally influential and valuable (and in some respects still unique) contribution to the theory of private-law rights in civil-law systems. The combination of a critique of private-rights theory and a critical evaluation of the social and political implications of legal technocracy that I strive for in this article is testimony of the kind of legal theory and practice I associate with Johan van der Vyver as a teacher and a colleague.

\subsection{The "background" law: The civil-law hierarchy of property rights}

Being a private law specialist brought up in the thin air of "pure" civil-law theory, I am primarily interested in the nature and content of property rights; in this case, land rights. However, I approach the matter from a Realist perspective, and consequently this is not a purely academic interest, since the creations of the land reform programme must fit in with and survive in the current South African system of property rights, which is still dominated by civil-law concepts and institutions. I am, therefore, interested in the potential and actual effect of land reform on the existing distribution of property, wealth and power in South African society.

Translated into very simple terms, one can say that the South African system of land rights has always privileged the institution of ownership, and in fact the whole system of apartheid land laws was built on and upheld in terms of this privilege. Both big1 and small ${ }^{2}$ apartheid were founded on and made possible by

1 Relating to homeland policies, which meant that black South Africans had to acquire and exercise land rights in specified parts of the country. The most important laws were the so-called "Land Acts": the Black Land Act 27 of 1913 and the Development Trust and Land Act 18 of 1936. See further the Black Areas Regulations PR 188, Government Gazette 2486 of 1969-07. 11 (issued in terms of s. 25 of the Black Administration Act 38 of 1927 and s. 21(1) of the Development Trust and Land Act 18 of 1936). See Van der Walt (1990:4ff, 16-17) and other sources referred to there 
the hierarchical primacy of ownership: the (im)possibility to acquire and exercise land-use rights was ultimately determined by the (im)possibility of owning land in a certain area. The supremacy of white land rights and the deficiencies of black land rights under the apartheid regime were of course primarily the result of political choices and the concomitant inequitable division of available land, ${ }^{3}$ but the deficiencies of black land rights were supported and exacerbated by the hierarchical civil-law property system. Even apart from the underlying political choices and policies, white land rights were strong and efficient because they were defined and protected in terms of the strong ownership paradigm, whereas black land rights, for the most part consisting of either traditional tribal land rights ${ }^{4}$ or statutory land "rights" such as site permits, residential permits, lodger's permits, hostel permits or certificates of occupation, 5 were weak and insecure because they were defined and treated as unrecognised and unprotected property relations. In terms of the hierarchical civil-law system of property rights, none of the black land rights was secure or strong in the sense that they could compete with or be weighed against "traditional" civil-law land rights, nor were they suitable in the sense that they could support those living on the land or provide legal security for bonds or loans. Most black land was cut off from markets and

2 Referring to land rights and land-use rights in urban areas, where white, black, coloured and Asian people were assigned special residential areas and business areas where they could acquire and exercise land rights. The most important laws were the Group Areas Act 36 of 1966; the Prevention of Illegal Squatting Act 52 of 1951; the Trespass Act 6 of 1959; the Health Act 63 of 1977; the Black Administration Act 38 of 1927 and the Regulations for the Administration and Control of Townships in Black Areas R 293 Government Gazette 373 of 1962-11-16 and the proclamations that succeeded them; the Black Local Authorities Act 102 of 1982; the Black Communities Development Act 4 of 1984 and the Regulations for the Administration and Supervision of a Black Urban Residential Area and Related Issues R 1036, Government Gazette 2096 of 1968-06-14 (issued in terms of s. 38(8)(a) of the Blacks (Urban Areas) Consolidation Act 25 of 1945). See Van der Walt (1990:18ff, 26ff) and other sources referred to there

3 Traditionally it is said that, under the apartheid land regime, more than $80 \%$ of the people in the country were forced to live on less than $13 \%$ of the total land available

4 Apart from the traditional weaknesses and potential insecurities of tribal land rights, these rights were placed under enormous strain because of the socio-economic system (migrancy labour that caused many young people to leave the homelands in search of cash income; too many people on too little land resulting in insecure and inefficient subsistence farming), and further eroded by apartheid legislation that distorted traditional sovereignty structures and defined the nature and content of the land rights involved - see the laws referred to in $\mathrm{fn}$. $\mathbf{l}$ above. See further Wilson and Ramphele (1989); Cross and Haines (1988); De Klerk ed. (1991). This already unacceptable position was rendered positively outrageous when victims of forced removals from white areas were "dumped" in areas already occupied by other black groups and communities, thereby creating layers of conflicting black land-use rights and claims. 
from economic infrastructure. By definition, living on black land meant poverty. Although the choice to structure the distribution of land and, consequently, of power along these lines was political, and although the actual embodiment of this distribution was created through legislation that seemed to have little bearing on property law as such, the framework for the effective implementation of apartheid land law was provided by the seemingly "neutral" structure of civil-law property institutions.

In a nutshell, the apartheid land-rights regime was based on the relative strength and security of white land rights, combined with the relative weakness and insecurity of black land rights. My point is that this division of strong and weak rights may look like a purely political creation, but in fact it was founded on (and, legally speaking, exacerbated by) a highly valued legal institution, namely the traditional civil-law hierarchy of property rights ${ }^{6}$. The apartheid land-rights regime exploited the power relations implicit in this hierarchy to ensure the political domination and the legal security that entrenched white privilege, and this hierarchy of power was not only upheld because of racial-political choice, but also strengthened by legal-dogmatical choice in privileging traditional, commonlaw institutions. Interestingly enough, this does not mean that traditional, civil-law property institutions were considered inviolable: a number of quite creative statutory deviations from tradition were introduced (and accepted as justifiable) during the apartheid era to make room for new developments and demands in the commercial property sector, but these "new patterns of landownership"7 served the purposes of high-finance development and the provision of upper-class housing, holiday accommodation and commercial premises; none of these developments was aimed at or served the land-use needs of the underprivileged, the homeless, the poor, or those who have been disadvantaged or dispossessed under the apartheid regime. Innovation and creativity seem to have been reserved for the entrenchment of privilege, not for the struggle against poverty and inequality. The social and political engineers who created apartheid land law

6 A hierarchy that consisted of ownershyp, the strongest right, at the top; followed by the limited real rights (servitude, real security rights); followed by personal rights (deriving from contract), followed by statutory use-rights and permits with little or no security. This hierarchy was informed by and based on the property theory of authorities such as Hugo Grotius and Bernhard Windscheid (see Van der Walt, 1993:569-589; Van der Walt, 1995:298-345). See further Van der Walt (1992:431-450) for an early plea in favour of abandoning the ownership paradigm and moving towards a "fragmented" system of land rights.

7 A term borrowed from Cowen (1984; see further Van der Walt, 1991a:1-7) The developments often referred to with this term are sectional title ownership (Sectional Titles Act 66 of 1971 , replaced by the Sectional Titles Act 95 of 1986); property time-sharing (Property Time-Sharing Control Act 75 of 1983); and shareblock holding (Share Blocks Control Act 59 of 1980). See Van der Walt (1991b:26 ff) for references. 
were quite at home with the post-Realist notion that rights are socio-political artefacts, and they were alive to the instrumentalist potential of this notion. In view of this background it is ironic that the handwork of these instrumentalists has so seldom been subjected to thoroughgoing Realist analysis and evaluation.

\subsection{Land reform and the transformation of "background law"}

When the land reform programme was initiated, one of the fundamental questions that was raised, albeit mostly from outside the corridors of political power, was how to not only address the existing inequalities in land distribution, but also overcome the structural inequalities that were built into this hierarchical system of land rights, as it appeared from the relative strengths and weaknesses of white and black land rights and the unequal distribution of wealth and power supported by them. The answer to this question relates to the purpose of my article: how could land-reform policy be shaped to address this underlying, structural hierarchy of civil-law property rights, and is it possible to identify (implicit or explicit) policy choices with regard to the privileging of certain property rights in land-reform initiatives to date? Regardless of efforts to effect a more equitable distribution of land, it is my contention that a land-reform programme that continues to privilege ownership above other property rights will, at least to a certain extent, uphold the existing hierarchical structures that formed the backbone of the apartheid land regime and continue the hierarchies of power that underlie land distribution patterns. Conversely, a land-reform programme will theoretically have the biggest structural impact on existing land-distribution patterns and land-related hierarchies of power if (and in so far as) it succeeds in breaking down or undermining the hegemony of land rights that are clustered around the structural and legal supremacy of the traditional ownership paradigm.

Pleas 8 for the "fragmentation" of land rights have to be understood against this background: the land-reform programme should break out of (and break down) the traditional, civil-law hierarchy of land rights, and create land rights that are strong and valuable because they suit specific needs and requirements, and not because they assume a privileged position in an abstract hierarchy of stronger and weaker rights. This will help to undermine the hegemony of the traditional system of property rights and its privileging of existing, mostly white, land rights. Stated very simply, this amounts to saying that land reform should consider the reform

8 See Van der Walt (1992:431-450; compare Van der Walt, 1995:298-345). From a theoretical point of view the purpose of the plea for fragmentation can be seen in relation to its opposition to the idea of metaphysical and structural-dogmatic unity. (For the opposite view, compare Brudner, 1995:21ff (chap II is entitled "The unity of property law"). See also Weinrib (1995: 196-203). 
and redistribution of land rights and not just (or simply) the redistribution of land. Land reform should amount to more than a merely superficial, mechanical reshuffling of land - if it is to be effective, it has to change the "background law" that formed the basis on which apartheid land law was constructed.

Another way of explaining my interest in the policy decisions behind the landreform programme is to refer, very briefly, to the work of the American Realists during the first decades of this century. The Realists are credited for initiating the critical approach that still characterises influential parts of current American thinking, and a major aspect of this critical approach consists of exploring the underlying power structures beneath the surface of property institutions, rules and practices. ${ }^{9}$ Following the cue provided by Holmes, the Realists pointed out that the law should be judged by its effects, and that the practical effects of the law are determined by the power relations that are embedded in what only seem to be neutral, apolitical institutions, rules and practices. Consequently, as is perhaps most obvious in American discussions about transformative processes related to labour rights ${ }^{10}$ and welfare rights, ${ }^{11}$ it is sometimes said that the actual effect of legal reforms should not be judged only with regard to changes on the surface of legal rules, institutions and practices, but also with special attention for the actual effect of these changes on what has been referred to as "background law"; the backdrop of underlying power relations that are embedded in existing law.

Oliver Wendell Holmes (see Holmes, 1897:457ff.) and the so-called Progressives (see Alexander, 1997.31 lff.) like Hohfeld (see Hohfeld, 1913:16ff; 1917:710ff), Felix Cohen (see Cohen, 1935:809ff, 1937:5ff), Morris Cohen (see Cohen, 1927:8ff.) and Hale (see Hale, 1923: 470ff.) are usually regarded as the most important early figures. For a general overview see Alexander (1997:31 lff), Grey (1989:787ff); Singer (1988:467ff), Horwtz (1992:109ff, 169ff).

10 A good recent example of an analysis of this kind is provided by Klare (1994:310ff). Klare investigates the possibilities for the transformation of property holdings in post-1989 Middle and Eastern Europe, especially through various alternative schemes of participation rights in commercial property, and points out the danger of superficial reforms and changes that do not succeed in actually changing the underlying power structures that determine the distribution of income and wealth

11 The most influential text in this regard is Reich (1964:733ff). For more recent commentaries see Simon (1985:Iff; 1986:1431ff; 1991:1335ff); Williams (1998:569ff). Reich's very influential article did not succeed in really transformung the underlying power structures that determine the distribution of wealth and income, and the subsequent analyses of authors such as Simons and Williams therefore continue the critical discussion. Williams points out that one of the most obvious indications of failure is the division that was created between the recognition and protection of social security rights (which were "carned" by way of some kind of contribution from the beneficiary) and "true" welfare payments (where there is no question of "eaming" the payment). A similar division is possible whth regard to both labour rights and land-reform rights (the latter with regard to restitution claims and tenure security for unlawful occupants respectively). 
According to this kind of critical analysis, legal changes and reforms can, and often do, amount to little more than superficial, cosmetic adaptations that do not change, undermine or threaten the existing distribution of property, wealth and power in society at all. In fact, in many cases the supposed reforms can actually insulate or reinforce the underlying power and property structures rather than change them. It is therefore necessary, once one accepts the validity of the Realist approach, to evaluate the land reform programme with a view to determining whether these reforms succeed in changing the basic power structure, the "background law", that underpins the current distribution of land and wealth in South Africa. My hypothesis is that the hierarchical structure of civil-law property institutions was and continues to be a major force in the creation and continuation of the current inequitable distribution of land, wealth and socio-political power in South Africa, and that an effective land-reform programme has to change or undermine that structure by changing the nature and coherence of the underlying legal system as such. In the American legal-theoretical context this project sounds trite; for property law specialists in a civil-law system its implications are revolutionary.

My analysis in this article relies upon two notions that are, to my mind, of the utmost importance for the current development of property theory and land-rights policy. In the context of the new constitutional order, with the emphasis it places on the importance of land reform and the aspiration towards equality and human dignity, property (and especially land) rights need to transform the existing property system in that it should satisfy both a threshold and a ceiling requirement. My argument is that the ownership-oriented model does not and cannot satisfy either requirement without substantial legislative amendment, whereas a use-rights oriented model can satisfy both requirements. The threshold requirement means that every land right that is or should be recognised in terms of the new constitutional order should be lifted above a certain threshold of minimum legal recognition and security - the very essence of apartheid law was that some (black) land rights were not so recognised or protected. The ownershiporiented property model tends to define and recognise all property rights from the perspective of civil-law, individual ownership, and this easily results (as is clear from the history of apartheid) that many rights and interests will not be recognised or protected simply because they do not fit into the conceptual, social and philosophical framework upon which the civil-law notion of individual ownership rests. The ceiling requirement refers to the now fairly widely accepted idea that property rights, including ownership, cannot be said to be absolute or unrestricted, not even in principle, because it is necessary and in fact unavoidable that all property rights should be restricted inherently by the exigencies of social structures and the public interest, even though the exact nature and scope of individual restrictions may be contingent and even negotiable. The hierarchical ownership-oriented model of property rights tends to resist the notion of a ceiling, 
but the rights-oriented model makes it much easier to accept and work with the idea of a ceiling that subjects all property rights to certain restrictions. The landreform programme will, therefore, succeed more easily in really transforming the underlying structure of land law if it succeeds in breaking down the hegemony of the ownership-oriented system and in promoting a use-rights oriented system of land rights.

\subsection{The choice between an ownership paradigm and a use- rights paradigm}

Against this background it is interesting to consider some of the general aspects of a policy choice in favour of either a (hierarchical) ownership-dominated or a (fragmented) use-rights dominated system of land rights. The ideas in this part of my analysis are still undeveloped and preliminary, and require further work. However, they offer an interesting perspective on the meaning and implications of the policy choices that are involved. From the discussion it will be clear that I favour a land-reform policy that will promote and develop a stronger use-rights orientation and move away from the traditional ownership-orientation that informs our common-law property system. This preference and the comparison upon which it is based presuppose that a system based on ownership (like our civil-law system) inherently involves a hierarchy of stronger and weaker rights, where ownership is the paradigmatic right in terms of which other rights are created and evaluated; while a system based on fragmented use-rights will produce a range of land rights that are intrinsically incapable of being classified as weaker or stronger, with each right being recognised and protected (often by legislation) on its own merits and according to its own context. At the same time, a stronger focus on a use-rights system will inevitably weaken or restrict the scope of ownership rights, thereby providing real possibilities for the redistribution of wealth and power.

I am therefore arguing that one useful perspective on the transformation of the traditional property hierarchy is to determine whether the land-reform programme still privileges the ownership paradigm, or whether it succeeds in switching to a less hierarchical paradigm, in which the focus is on the creation and reinforcement of use rights rather than on ownership of land. My suggestion is that the former approach will tend to reinforce and uphold the existing distribution of property, wealth and power, whereas the latter offers better possibilities for undermining and changing the existing position. A comparison of some of the contrasting characteristics of the two approaches illustrates the differences between their respective effects on the property system as a whole: 
Property rights and hlerarchles of power: a critlcal evaluotion of land-reform pollcy in SA

Ownership
Based on a hierarchy of rights
Title and use normally united
Security depends on title
No title means no security
Tends to resist regulation
No natural ceiling ("absolute")
Supports hierarchy of power

\section{Use rights}

No hierarchy of rights

Title and use mostly separated

Security by legislation

Statutory security threshold

Tends to absorb regulation

Natural ceiling of restrictions

No inherent power relations

Because of the focus on ownership, title and use tend to be united in one hand in the ownership-oriented systems, rather than being spread over a range of right holders. In the terminology of Windscheid, ownership is capable of being restricted and limited real rights can be created in favour of other parties, but the right itself is elastic and reverts to its full status as soon as the (temporary) restriction caused by a limited real right falls away. The same principle holds as far as restrictions of the owner's use rights are concerned: they are possible, but exceptional and temporary, and as soon as they fall away ownership reverts to the "normal" position of being unrestricted. This means that ownership in principle resists restrictions and regulation in the public interest. Although restrictions and the creation of limited real rights that will split use from title are possible, the "normal" position is that title and use are united in one hand - that of the owner and that the owner's right of use is unrestricted. This obviously places certain structural-conceptual restrictions on the possibility of creating land rights that do not depend on the ownership paradigm. That in turn means that land rights ideally have to assume the form either of ownership or of rights that derive from, depend upon and are weaker than ownership. Because of the underlying hierarchy of power, the owner's security of tenure depends upon the law's recognition of title, while all other rights are either secure because of the temporary creation of limited real rights from the "mother right", ownership, or they are insecure because they do not include title. This situation obviously upholds the hierachy of rights and the underlying hierarchies of power that helped to create the existing inequalities in the land distribution pattern we know as apartheid land law.

A system of property rights that is not dominated by the ownership paradigm, on the other hand, can consist of a variety of use rights that are not structurally or hierarchically related and that is not dominated by a single, superior right that is stronger than other rights. Such a system of land rights does not necessarily support a hierarchy of power relations because it does not consist of and is not based on a hierarchy of rights. It is infinitely flexible and context-sensitive, because new rights can be created and existing rights can be adapted to suit the needs and requirements of the land-use situation, and without reference to some structural or conceptual paradigm. Similarly, rights in such a system will tend to absorb regulation and restrictions that are imposed in the public interest because 
of the spread of use rights and entitlements between a number of users. Title is not an important factor for security of tenure, because security is created and ensured by suitable legislation as and when required.

\subsection{Structure of the article}

In the rest of this article I analyse the most important land reform policies, programmes and laws since 1991 and establish, as far as possible, the (explicit or implicit, conscious or unconscious) policy choices they embody or represent, judged against the background of the considerations I discussed above. The analysis is divided into three main parts according to what the Reconstruction and Development Programme described as the three pillars of land reform:12 the restitution of land rights, ${ }^{13}$ the redistribution of land ${ }^{14}$ and tenure reform. ${ }^{15}$

12 The division on land reform is derived from the Reconstruction and Development Programme: see the policy document of the ANC (1994: 19ff item 2.4); as well as the 1994 White Paper on Reconstruction and Development on 1.3.6 p. 5, Lead Projects on p. 48ff; the 1997 White Paper on South African Land Policy on p. vi, viii, 9, 10. The three aspects of land reform are now formally sanctioned and controlled by ss. 25(5) (redistribution), 25(6) (tenure reform) and 25(7) (restitution) of the property clause in the 1996 Constitution. The 1997 White Paper on $p 7$ identifies the following overall objectives of land reform: to eradicate injustices of racially based dispossessions; to promote a more equitable distribution of land ownership (sic), to reduce poverty and promote economic growth through land reform; to provide security of tenure for all; and to establish a system of land management that will support sustainable land-use patterns and rapid land release for development. On p. 12 (Box 2.3) the following principles are enumerated: social justice; poverty focus; needs-based; government as facilitator; flexibility; participation, accountability, and democratic decision-making; gender equity; economic viability and environmental sustainability. Under the "flexibility" heading, nothing specific is said about tenure forms. In Box 3.4 on p. 33, factors that affect the pressure for individual land rights (as opposed to communal tenure) are enumerated the relative importance of issues such as access to credit, access to markets and quality of land as opposed to the productivity debate; advantages of social backup and free access to land in communal systems as opposed to overcrowding in individually owned areas; access to markets tends to promote individual rights; the challenge is to provide for flexibility, variety and change over time.

13 As concerns the restitution of land rights, see s. 25(7) of the 1996 Constitution. Restitution is defined as a limited process by which specific parcels of land (or altemative land or compensation) are returned to specific people (or their direct descendants) from whom it had been taken (whether by due process of law or not) in terms of racially discriminatory laws. This process has a limited lifespan. In the 1997 White Paper on South African Land Palicy on p. viii the following restitution issues are identified: ensure that those dispossessed of land after 1913 get restitution in the form of land or other remedies; ensure that appropriate administrative and financial arrangements are in place to deal with claims; respond suitably to claims in urban areas where land has been developed and has changed hands; ensure participation of all role players in the restitution process. See further p. 29-30

14 Regarding the redistribution of land see s. 25(5) of the 1996 Constitution. Redistribution is a less limited process by which land or access to land is given or made available to people who have no land or inadequate land, either for agricultural (subsistence or commercial) or 
In the concluding section of the article I summarise the policy choices identified in the course of the analysis, followed by an evaluation of these policy choices, a brief consideration of some possible alternatives, and a few concluding remarks about the implications of the choices embodied in the land reform laws.

\section{Restitution policy and laws}

\subsection{Definition of restitution as a form of land reform}

Restitution is a limited process with a limited lifespan, ${ }^{16}$ and is aimed at returning specific parcels of land to specific people from whom it had been taken in terms

residential purposes. In the 1997 White Paper on South African Land Policy on p. viii the following redistribution issues are identified: how to respond appropriately to widely differing needs and aspirations of people for land in urban and rural areas in a manner that is equitable, affordable and that will contribute to alleviate poverty and stimulate growth; how to address immediate and urgent cases of landlessness and homelessness that cause land invasions, how to make available commonage to poor residents of rural towns who wish to supplement their incomes. See further pp. 27-29, where the interesting concept of municipal commonage is mentioned. Programmes and financial incentives are planned to encourage municipalities to establish and/or use a municipal commonage for land reform purposes, notably to assist poor people to supplement their income.

15 For more detail on tenure reform see s. 25(6) of the 1996 Constitution. Tenure reform is a process by which insecure or unsuitable forms of existing land tenure are transformed legally to provide better or more suitable rights. This can concern the security of the landholding as such, or the possibility of procuring loans with the land right as security, or any aspect of the tenure under which the land right is held or exercised. In the 1997 White Paper on South African Land Policy on p. viii the following tenure reform issues are identified: how to upgrade the variety of conditional tenure arrangements that restrict security of tenure and investment opportunities of people; how to resolve overlapping and competing tenure claims of people forcibly removed from their land and resettled on land where others had prior rights; how to strengthen beneficial aspects of communal tenure systems and simultaneously address negative aspects that erode tenure rights and degrade natural resources; how to assist communities with no legally secure rights on land earmarked for development; how to provide security of tenure to people living on land belonging to others, especially farms. See further p. 30-34, where the following tenure problems are identified: inferior black land rights are vulnerable and make it impossible to secure financing; overcrowding and forced overlapping of land rights, especially in rural areas; problems caused by communal tenure systems; informal settlements in urban areas and lack of services; discrimination against women, especially in communal systems; insecurity of people who live on other peoples' land, especially farms.

16 S. 121(3) (read with s. 121(2)(a)) of the Constitution of the Republic of South Africa 200 of 1993 and s. 2(3) of the subsequently promulgated Restitution of Land Rights Act 22 of 1994 determine that restitution claims are not possible for dispossessions that took place before 19 June 1913 (the promulgation date of the Black Land Act 27 of 1913). S. 2(1)(b) of Act 22 of 1994, read with s. 3(1) of the Land Restitution and Reform Laws Amendment Act 63 of 1997, restricts the restitution process to claims that are lodged not later than 31 December 1998 (but see further Roux, 1998:3A-5 fn 1; 3A-22-3A-23). Further restrictions are laid down in s. 121 of the 1993 Constitution; such as that the process shall not apply to land rights expropriated under the Expropriation Act 63 of 1975 (or any act incorporating that Act by reference) for which just 
of racially discriminatory laws or practices during the apartheid era. In the former National Party government's initial proposal for land reforms, the position was still that "a programme for the restoration of land to individuals and communities who were forced to give up their land on account of past policies or other historical reasons would not be feasible." (See the 1991 White Paper on Land Reform p. 6 item A2.(f).) However, when the Abolition of Racially Based Land Measures Act 108 of 1991 that was foreseen in this 1991 White Paper was eventually promulgated, it included a Chapter VI that provided for the appointment of an Advisory Committee on Land Allocation, ${ }^{17}$ which was charged with the implementation of a very limited form of land restitution. ${ }^{18}$ Sections 121 123 of the 1993 Constitution made provision for a more extensive process of restitution in terms of a law that had to be promulgated to control this process, and the Restitution of Land Rights Act 22 of 1994 was duly promulgated to fulfil this function. Certain provisions of the 1994 Act were amended by the Land Restitution and Reform Laws Amendment Act 63 of 1997.

\subsection{Restitution laws}

The long title of the 1994 Act states that the purpose of the Act is "to provide for the restitution of rights in land in respect of which persons or communities were dispossessed under or for the purpose of furthering the objects of any racially discriminatory law". 19 This purpose was reiterated in the original preamble to the Act:

Whereas the Constitution ... provides for the restitution of a right in land to a person or community dispossessed under or for the purpose of furthering the

and equitable compensation had been paid (s 12l(4)). The intended time schedules for the restitution programme are set out in the 1997 White Paper p. 53 Box 4.7. See further Roux (1998:3A-5; 3A-8).

17 Changed to the Commission of Land Allocation, with slightly extended powers and functions, by s. 4 of the Abolition of Racially Based Land Measures Amendment Act 110 of 1993.

18 Referred to as "land allocation". The Commission's function was basically to establish whether a person or group had been dispossessed of land under a past racially discriminatory law that was repealed by the Act, and whether the dispossession could be rectified by way of allocation of that or other state land. In some cases the Commission could make a binding order on this matter, in other cases it was restricted to a recommendation to the minister of land affairs

19 S. 31 of the 1997 Amendment Act amended the long title to read "[t]o provide for the restitution of rights in land to persons or communities dispossessed of such rights after 19 June 1913 as a result of past racially discriminatory laws or practices; ..." See fn. 13 above for a summary of restitution policy in the 1997 White Paper on South African Land Policy, and see pp. 52-61 for a discussion of the restitution programme. The restitution programme is now formally sanctioned and controlled by s. 25(7) of the 1996 Constitution. The main sources on this Act are Jaichand (1997); Roux (1998) 
Property rights and hierarchies of power: a critical evaluation of land-reform policy in SA

objects of any racially discriminatory law; and whereas legislation for this purpose is to be designed to promote the protection and advancement of persons, groups or categories of persons disadvantaged by unfair discrimination, in order to promote their full and equal enjoyment of rights in land: Now therefore be it enacted ...

The preamble was amended by the Land Restitution and Reform Laws Amendment Act 63 of 199720 to make it clear that the restitution process is not restricted to actual restoration of land, but includes restitution of any property (including but not restricted to land rights) as well as equitable redress, and that a major purpose of the Act is to achieve equality, in line with the Constitution of 1996.21 The restitution process is now authorised and controlled by a special provision in the property clause in the 1996 Constitution: section $25(7)$ of the final Constitution provides that

... [a] person or community dispossessed of property after 19 June 1913 as a result of past racially discriminatory laws or practices is entitled, to the extent provided for by an Act of Parliament, either to restitution of that property or to equitable redress.

Consequently the process is no longer restricted to land or to rights in land. Even though the original parameters of the restitution process were drawn with specific reference to "rights in land",22 the 1993 Constitution (s. 123) and the original version of the $1994 \mathrm{Act}^{23}$ made provision for alternative relief, particularly awards of alternative land (1993 Constitution s. 123(3)(a)), compensation awards (1993 Constitution s. 123(3)(b)), and other alternative forms of relief (1993

20 S. 1. The preamble now reads "Whereas the Constitution ... provides for restitution of property or equitable redress to a person or community dispossessed of property after 19 June 1913 as a result of past racially discriminatory laws or practices; And whereas legislative measures designed to protect or advance persons, or categories of persons, disadvantaged by unfair discrimination may be taken to promote the achievement of equality; Now therefore be it enacted

..." See Du Plessis et al. (1997b:532 ff) on the Amendment Bill

21 See ss. $1(a), 7(1), 36(1)$ of the Constitution, and compare s. 9.

22 "Right in land" is defined in s. 1 of the 1994 Act as "any right in land whether registered or unregistered, and may include the interest of a labour tenant and sharecropper, a customary law interest, the interest of a beneficiary under a trust arrangement and beneficial occupation for a continuous period of not less than 10 years prior to the dispossession in question". This definition was left unchanged by the 1997 Amendment Act. Compare the full discussion by Roux (1998 3A-13-3A-16)

23 S. 35 . The original provisions of s. 35 have been amended extensively by s. 25 of the 1997 Amendment Act, but it still provides for alternative relief as one of the options open to the Land Claims Court in making a restitution award. See further the 1997 White Paper p. 55-57; Jaichand (1997: 53 fl. 164, 65-67) 
André van der Walt

Constitution s. $123(3)\left(\right.$ c)), for example support from state housing programmes, ${ }^{24}$ in cases where actual restitution of the land that was dispossessed was impossible or unfeasible ${ }^{25}$ or where the claimant preferred alternative relief. ${ }^{26}$

\subsection{Evaluation of restltution policy}

Obviously, the notion of restitution means that the restitution process has to be aimed primarily at the actual giving back or restoration of land, including land rights as defined in the Act, ${ }^{27}$ but the idea was never to interpret or apply this principle too narrowly. This is clear from section 35(4) of the 1994 Act, which provides that the Land Claim Court's power to grant a restitution order "or to grant a right in alternative state-owned land (1993 Constitution s. 123(3)(a)) shall include the power to adjust the nature of the right previously held by the claimant, and to determine the form of title under which the right may be held in future". The purpose of this provision was to ensure that the restitution award could include a suitable adjustment to rectify the insecurity that might inhere in the land right in question, thereby preventing a situation where the restitution award is followed by an eviction or a conflict with other rights. Similarly, the provisions of

24

1994 Act s. 35(1), s 35(2)(d). This provision was repealed by the 1997 Amendment Act s. 25.

25 Restitution may be impossible or unfeasible because the land in question has been transferred to a private person and cannot be recovered or bought back, or because it is used for a public purpose: 1993 Constitution s. 123(1); 1994 Act s. 35(2). Also see Roux (1998:3A-45-3A-48)

261993 Constitution s. 123(3). Two good examples of cases where the claimant preferred altemative relief were reported in decisions of the Land Claims Court recently (also see Du Plessis et al., 1997b:536-537). In Dulabh and Another. Department of Land Affairs 1997 (4) SA 1108 (LCC) the Land Claims Court decided that a claimant who could prove his restintion claim, but who had used own initiative and resources to repurchase the land while waiting for the lengthy restitution process, could claim compensation instead of the actual restitution of the land. In Ex parte North Central and South Central Metropolitan Substructure Councils of the Durban Metropolitan Area and Another 1998 (1) SA 78 (LCC), the Land Claims Court decided that it could incorporate a settlement agreement into a restitution order even if the settlement order made provision for certain developments that imply that some restitution claims have to be substituted by awards of alternative land or altemative rights with regard to the developments in question, as long as the settlement agreement as a whole was still in the public interest as required by s. 34 of the 1994 Act. For further decisions on this Act see Blaauwberg Municipality v. Bekker and Others LCC 17/1996; Mayibuye 1-Cremin Committee Land Claim LCC 28/1996; Ex parte Elandskloof Vereniging LCC 20/1996; Nchabeleng v. Phasha LCC 24/1996; Ex parte Beukes and Bekker LCC 17/1996; Farjas and Another $v$. The Regional Land Claims Commissioner, KwaZulu-Natal LCC 21/1996; Hlatswayo and Others v. Hein LCC 31/1996 (now reported: 1998 (1) BCLR 123 (LCC)); Ngcobo and Another v. Van Rensburg and Others 18/1996. (Note: both summaries and full text of unreported decisions of the Land Claims Court can be found on the Website http://www.law.wits.ac.za)

27 See the explanation in $\mathrm{fn} .22$ above. 
section $35(2)(c)$ and $35(3)$ indicate that a restitution order should take into account and make adequate provision for traditional or tribal land rights when making an order to a community, to ensure that all members of the community receive equal access to the land awarded, and that the land is held in a manner that suits the circumstances. However, apart from these indications of openendedness, neither the 1993 Constitution ${ }^{28}$ nor the 1994 Act $^{29}$ (or the 1997 Amendment Act $)^{30}$ prescribes the exact nature or content of the rights that could or should be included in a restitution order. The idea probably is that the actual transformation of existing land rights and the creation of new land rights is left to laws concerned with tenure reform, while the Restitution Act simply keeps the options for restitution awards as open as possible. This impression is confirmed by the subsequently promulgated Communal Property Associations Act 28 of 1996 , which provides that a restitution award to a community shall be made in terms of the tenure framework set out in the 1996 Act (s. 2)

28 Ss. 121-123. The strongest indication of open-endedness here is that these sections, in line with the property clause in s. 28(1) of the Constitution, referred to "rights in land" and not simply to land, thereby indicating that a variety of rights could be claimed and awarded in a restitution case. S. 123(1)(a) provided, for example, that the state could be ordered to restore "the relevant right" to the claimant if the land in question is still "in the possession" (by which is no doubt meant "owned") by the state when the claim is lodged; $s$. 123(1)(b) similarly provides that the state can be ordered to repurchase land that is owned by ("in the possession of") a private owner and then to restore "the relevant right"; s. 123(3)(a) provides that, if the land is not owned by the state and it is not feasible to buy it, the state can be ordered to grant the claimant "an appropriate right" in aiternative state land, thereby indicating a clear distinction between the land and the rights in that land

29 See th. 22 above on the definition of "right in land" in $\mathrm{s}$. 1 of the Act The Act, which was promulgated under the auspices of $\mathrm{s} .28$ and ss. 121-123 of the 1993 Constitution, still referred exclusively to the restitution of "rights in land", see ss. 2(1); 6(1)(a), 10(1); 15(1);33(a); 35(2).

30 The most obvious amendment is that some references to "rights in land" in the 1994 Act are replaced by references to "property", in line with the move away from "rights in property" in s 28 of the 1993 Constitution to "property" in s. 25 of the 1996 Constitution: see the new preamble (Amendment Act s. 1). References to and the definition of "right in land" are, however, retained in most of the Act. The open-ended nature of the rights to be restored is not affected by the amendments: s. 35 of the 1994 Act is amended by s. 25 of the 1997 Amendment Act to provide that the Land Claims Court may order "the restitution of land, a portion of land or any right in land" (s. 35(1)(a) as amended), while retaining the further possibilities of compensation and alternative relief. The provisions of $s$. 35 with regard to the suitability of an order to the manner in which rights have to be held if the claimant is a community are also retained. An interesting novelty is s. 30 of the 1997 Amendment Act, which introduces a new s. 42A to the main Act, providing for a restitution order that includes an order to the state to acquire or expropriate land in order to effect the restitution or award: the claimant shall become owner of the land on the date of acquisition or expropriation, and no duty, fee or charge is payable in regard to registration of the land in the claimant's name (in South African law, registration is required for the vesting of ownership in land, except when the land is acquired originally, e.g. by way of expropriation). See Jaichand (1997:53 fn. 164, 65-67). 
The conclusion, as far as the Restitution of Land Rights Act 22 of 1994 is concerned, is that the Act aims to break away from the hegemony of the ownership-oriented hierarchy of land rights; that it leaves room for restitution awards that reflect the difference between land and land rights; that it makes provision for restitution awards to individuals and to communities, and for land rights that suit the social and political position of individual members of a community; and that it makes provision for restitution awards that take cognisance of the potential weaknesses and insecurities of dispossessed land rights and that allow for the suitable adjustment and strengthening of the rights that are restored. However, none of the provisions in the Act explicitly breaks away from the structural and dogmatic hegemony of the common-law hierarchy of land rights, and the main focus of restitution orders will probably (and perhaps inevitably) continue to fall on the restitution of ownership in land. The only substantial exception is the possibility, created by section 2 of the Communal Property Associations Act, that some restitutions that involve communities may be structured in terms of the framework of communal property associations rather than in the form of individual common-law ownership.

\section{Redistribution policy and laws}

\subsection{Definition of redistribution as a form of land reform}

Redistribution of land is a wider project aimed at rectifying (some of) the inequalities in current land distribution patterns. While restitution involves the returning of land that was taken away during the apartheid era, and tenure reform involves the strengthening of rights of those who do have access to land, the redistribution effort is aimed mostly at those who did not have land before and still do not have (sufficient) land. This obviously involves a wide variety of different policies, strategies and projects. For the most part, the redistribution laws deal with either residential land (housing) or agricultural land (redistribution of larger-scale farming land). Land-reform laws that affect residential land rights are the Less Formal Township Establishment Act 112 of 1991, the Provision of Certain Land for Settlement Act 126 of 1993, the Development Facilitation Act 67 of 1995 and the Housing Act 107 of 1997.31

31 See fn. 14 above, and compare the 1997 White Paper pp. $36-51$ for an overview of redistribution programmes. The redistribution programme is now formally sanctioned and controlled by $\mathbf{s}$. 25(5) of the 1996 Constitution The programmes and initiatives that take the form of subsidies and grants are not considered here; see the 1997 White Paper p. 43, and compare p. 44 (Box 4.4: the individual settlement/land acquisition grant) and p. 46 (Box 4 : the Mayibuye programme, an urban pilot project based on the same settlement/land acquisition grant) and p. 49 (Box 4.6: schemes to promote agricultural land reform in partnerships with the private sector) 


\subsection{Redistribution laws and programmes}

One of the laws promulgated as part of the former National Party government's limited land reform proposals in 1991 was the Less Formal Township Establishment Act 112 of 1991. The Act, which was meant to help alleviate the housing shortage, ${ }^{32}$ provided simplified and shortened procedures for settlement of people and for the establishment of so-called "less formal settlements" that are more formalised than informal settlements or squatter camps, ${ }^{33}$ but still do not comply with normal development and building regulations and requirements. ${ }^{34}$ The Act did not make provision for land rights other than those recognised in common law ${ }^{35}$ or in customary law, ${ }^{36}$ and its inability to come to terms with the realities of land redistribution is illustrated by the way in which the Act resulted in litigation soon after its promulgation. ${ }^{37}$

The Provision of Certain Land for Settlement Act 126 of 1993 also made provision for the settlement of people on land designated by the administrator of a

32 In both urban and rural areas: the Act not only provides for speedy settlement in and for the speedy establishment of "less formal" urban settlements (Chap. I and Chap. 2), but also for the settlement of "indigenous tribes" in "less formal" rural settlements (Chap. 3).

33 Mostly in that basic services such as roads, potable water, some form of sanitation and sometimes even electricity is provided, and occupants are then allowed to erect (and extend) their own shelters or houses as they see fit and as they can afford.

34 The former government's 1991 White Paper on Land Reform emphasised the need for speedy development on p. 21-22.

35 In the case of speedy informal settlement (Chap. 1) s. 6(c) provides that ownership of public places in the township shall vest in the local authority or in the administrator in trust for a local authority to be established; s. 9 provides for the registration of ownership of an erf in the name of an individual occupant; in the case of speedy establishment of a "less formal" settlement (Chap. 2) ss. 17 and 19 contain similar provisions; in the case of a rural "less formal" settlement for indigenous tribes (Chap. 3) s. 24(2) provides that private law shall apply when a tribe transfers ownership of an erf to an individual. Ss. 25-26 provide for the granting and registration of private ownership in such a case.

36 In the case of a rural "less formal" settlement for indigenous tribes (Chap. 3) s. 24(1) provides that "the rights of a tribe member with regard to an erf" allocated to him by the tribe shall be governed by indigenous law and the customs of the tribe

37 In Diepsloot Residents ' and Landowners' Association v. Administrator, Transvaal 1994 (3) SA 336 (A) the former Appellate Division of the Supreme Court (now the Supreme Court of Appeal, see s. 166(b) of the 1996 Constitution) had to decide whether a decision of the former Administrator of a province to establish such a "less formal" settlement was valid. The residents of an established (white) township in the vicinity opposed the settlement, claiming that it would result in lower property values, increased pollution and crime. The Appellate Division upheld the settlement decision. 
province for that purpose. ${ }^{38}$ Once land has been designated, developed and subdivided, it could be transferred to and registered in the name of a new owner, ${ }^{39}$ and consequently the Act provides for settlement in terms of commonlaw ownership.

The Development Facilitation Act 67 of 199540 is a much more extensive and comprehensive piece of legislation that was also aimed at facilitating, simplifying and speeding up the delivery of housing, both in the rural and in the urban areas. ${ }^{41}$ Chapter 7 of the Act deals with land tenure, and is the most interesting part of the Act for present purposes. Section 62 creates a completely new land right, called "initial ownership", that may be registered as soon as the registrar has opened the relevant register with regard to the land. Initial ownership is created and registered at a stage before the land is fully developed, and the Act ensures that this form of ownership is so secure that it enables the initial owner to obtain financing to purchase the land, thereby reducing the development and holding cost considerably, and facilitating speedier and cheaper delivery of residential land. The holder of initial ownership may occupy and use the land, encumber it by a mortgage or personal servitude (but not otherwise), sell the initial ownership (but not full ownership), and acquire full ownership as soon as the development process reaches the stage where the land is fully registrable. ${ }^{\mathbf{4 2}}$ The Act further

38 S. 2. The settlement and land in the settlement could be used for residential purposes or for small-scale farming, business, community or public purposes: s. 5 . Regulations were proclaumed in Government Gazette 17570, 15-11-1996; see Du Plessis et al (1997a:261).

39 S. 9. The Act also provided for subsidies to facilitate the acquisition of land in such a settlement: ss. 10, 11. The functions of the administrator in this regard have been transferred to the minister of land affairs: items 1 and 3 of the Schedule: Laws Amended, Development Facilitation Act 67 of 1995

40 Which amended but did not repeal the Conversion of Certain Rights unto Leasehold or Ownership Act 81 of 1988, the Less Formal Township Establishment Act 113 of 1991, and the Provision of Certain Land for Settlement Act 126 of 1993. The main source on this Act is Latsky (1998).

41 Chapter 4 sets out land development objectives; Chapter 5 deals with procedures regarding the development of land excluding land used for small-scale faming; and Chapter 6 deals with procedures regarding the development of land including land used for small-scale farming. See Latsky (1998:2A-33-2A-37, 2A-45-2A-52)

42 S. 62. The effect is basically that registration of initial ownership is possible before full registration would have been possible, and because of the protection of a mortgagor in the Act (s. 62(8)), the owner is able to obtain financing at that early stage and avoid the financial burden that would normally rest on a developer. This is supposed to attract developers to development projects of land for a market that would otherwise have been too risky or unprofitable, thereby speeding up and facilitating the delivery of cheaper land for residential settlement See Latsky (1998:2A-72-2A-85) 
provides for the upgrading of informal or unregistered tenure arrangements in an existing settlement that is upgraded in terms of the Act, so that similar benefits become available to residents with insecure or informal tenure in existing settlements as those made available to prospective purchasers in a new settlement (s. 63). Despite the innovation involved in the creation and registration of initial ownership, which is a useful but ultimately still temporary and transitional arrangement, the Act does not create or promote alternative land rights: in the final analysis, it is aimed at the acquisition of (and promotes) common-law ownership of land.

The most recent redistribution law concerned with residential land, the Housing Act 107 of 1997, is meant to "provide for the facilitation of a sustainable housing development process", 43 and applies to the provision of housing on the national, provincial and local government levels. 44 Part 1 of the Act lays down the general principles that govern housing development, ${ }^{45}$ and the most interesting principles are that housing development should provide "as wide a choice of housing and tenure options as is reasonably possible",46 and that individuals and communities ${ }^{47}$ must be encouraged and supported in their efforts to fulfil their own housing needs, by assisting them in accessing land, services and technical assistance in a way that leads to the transfer of skills to and the empowerment of the community. 48 The general principles do not include security of tenure as a specific goal, but in view of the overarching guarantee provided by section 26 of the 1996 Constitution ${ }^{49}$ it may be assumed that security of tenure is a major value

43 Quoted from the long title of the Act. Du Plessis et al (1997b:543ff) discuss the Bill

44 The Act repealed a myriad of old, apartheid-style separate housing and development laws; see the Schedule in terms of s. 20 .

45 These principles are in accordance with s. 26 of the 1996 Constitution, which provides that (1) everyone has the right to have access to adequate housing; (2) the state must take reasonable legislative and other measures within its available resources to achieve the progressive realisation of this right; and (3) no one may be evicted from their home or have their home demolished without a court order that takes into account all relevant circumstances and that does not permit arbitrary evictions.

46 S. 2(1)(c)(i). This principle was already advocated in the 1994 White Paper: A National Housing Policy and Strategy for South Africa par. 5.7.4.2 at p. 58.

47 Which term includes but is not restricted to co-operatives, associations and other bodics which are community-based.

48 S 2(1)(d). This principle was already advocated in the 1994 White Paper: A National Housing Policy and Strategy for South Africa par 4.5 .1 on p. 24

49 See the explanation in fn. 45 above 
to be promoted by the housing policy. 50 The Act provides for the formulation of a national, as well as provincial, housing policy (ss. 3(2), 7(2)(a)), but apart from the principles mentioned above, nothing specific is provided in the Act that affects the nature of the land rights that are to be promoted or created in the housing policy or in the housing development process.

Apart from the laws that affect residential land rights, there are also land distribution initiatives aimed at unequal agricultural land distribution patterns. The most important initiatives are the Land Reform Pilot Project and the Land Reform (Labour Tenants) Act 3 of 1996.51 The Land Reform Pilot Project was identified in the government's White Paper on Reconstruction and Development and White Paper on South African Land Policy (Box 2.2 p. 10) as a lead project to "kick start" the land redistribution process in rural areas. The project was launched in 1994, and involved the identification of pilot areas in each province where existing land users could be assisted in acquiring additional land, as well as financial and technical assistance, to help them on the way to meaningful and sustainable land use. No specific principles or preferences regarding forms of tenure in these pilot projects are known, and it must be assumed that either common law ownership or tribal ownership dominate the projects, at least until the tenure reforms of 1996 were introduced. There is no reason why these projects cannot be implemented in terms of the tenure reform laws introduced in 1996.

The Land Reform (Labour Tenants) Act 3 of 1996 is partially redistributory and partially tenure reform in its orientation. The purpose of the Act is to provide for the security of tenure of labour tenants and persons occupying land as a result of their association with labour tenants (a tenure reform objective, discussed in the next section below); and to provide for the acquisition of land and rights in land by labour tenants (a redistributory objective). A labour tenant is defined in the Act as a person who resides or has the right to reside on a farm, who has or has had the right to use grazing or cropping land on the farm (or on another farm of the same owner), and in consideration for this right provides or has provided labour to the owner; and whose parent or grandparent satisfies or satisfied the requirement above with regard to land-use in exchange for labour, 52 Labour

50 This principle was already advocated in the 1994 White Paper. A Nathonal Housing Policy and Strategy for South Africa par. 5.7 .42 on p. 58.

51 As amended by the Land Restitution and Reform Laws Amendment Act 63 of 1997 . See Pienaar (1997:538-548) for a discussion.

52 S. 1(xi). See in this regard the decisions of the Land Claims Court in Mahlangu v. De Jager 1996 (3) SA 235 (LCC); Zulu and Others v. Van Rensburg and Others 1996 (4) SA 1236 (LCC), where the definition of a labour tenant was analysed and the differences between a 
tenants are explicitly distinguished from farmworkers, who are defined as persons employed on a farm in terms of a labour contract which provides that the farmworkers are paid predominantly in cash or another form of remuneration and not the right to occupy or use the land, and that the farmworkers are obliged to perform their duties in person. $\mathbf{5 3}$ For purposes of the Act, "rights in land" are defined as any real or personal right in land, including the right to share cropping or grazing. 54 The redistributory aspect of the Act is contained in Chapter III, which provides for the acquisition of ownership or other rights in land by the labour tenant. Labour tenants are granted a period of four years to lodge claims to acquire the land which they are entitled to occupy in terms of the labour tenancy agreement, or other land on the same farm or in the vicinity, as well as any other land rights like servitudes that they may have enjoyed as part of the labour tenancy or that are necessary for and consistent with their use of the land 55 In the

labour tenant and a farmworker elucidated. Despite the statement to the contrary in $Z u l u$ at 1253I-1254F, the Natal High Court has assumed the position that it is more logical that the three requirements in the definition of a labour tenant in $\mathbf{s} 1$ (xi) do not all have to be read conjunctively: either the first two or the first and third requirements are to be read conjunctively: see Klopper and Others v. Mkhize and Others 1998 (1) SA 406 (N); Tselentis Mining (Pty) Ltd and Another v. Mdlalose and Others 1998 (1) SA 411 (N). In Zulu, the Land Claims Court correctly decided that the parents and grandparents mentioned in s. 1(xi) did not have to satisfy the requirements in (a) and (b), but then also decided that the claimants themselves had to comply with (a), (b) and (c) cumulatively, so that a claimant whose parents did not satisfy the requirements of (c) would not quality as a labour tenant. The position in Klopper and Tselentts is that a person can qualify as a labour tenant by satisfying either the requirements in (a) and (b) or the requirements in (a) and (c). The Transvaal High Court has rejected the Natal position and adopted the Land Claims Court's decision in Zulu as the correct one: see Mosehla v. Sancor CC 1999 (1) SA 614 (T). The Land Claims Court has subsequently decided to uphold its earlier position: see Dhladhla and Others v. Erasmus 1999 (1) SA 1065 (LCC). S. 33 of the Land Restitution and Reform Laws Amendment Act 63 of 1997 amended s. 2 of the Labour Tenants Act by adding subss. (5) (creating a rebuttable assumption that a person who is proven to fall within the definition in (a), (b) and (c) as set out above is a labour tenant) and (6) (to establish whether a person is a labour tenant the court shall have regard to the combined effect of all agreements entered into between the claimant, her parents or grandparents and the owner or lessee of the land). For further case law see Linda v. Buhrman and Another LCC 11/1997; compare in. 26 above. Chapter 4 in Budlender et al. (1998) that deals with this Act contains no commentary.

53 S. 1(ix). See in this regard the decisions of the Land Claims Court in Mahlangu v. De Jager 1996 (3) SA 235 (LCC); Zulu and Others v. Van Rensburg and Others 1996 (4) SA 1236 (LCC), where the definitions of a labour tenant and a farmworker are distinguished However, with regard to the definition of a labour tenant see the previous footnote above.

54 S. I(xvi). See the decision in Zulu and Others v. Van Rensburg and Others 1996 (4) SA 1236 (LCC), where the Land Claims Court decided that an action that denied a labour tenant the right to graze amounted to an eviction in terms of the Act.

$55 \mathrm{~S}$ 16. The Act provides for an initial procedure for consideration of the claim (s. 17), settlement of the claim by agreement with the landowner (s. 18); arbitration proceedings (ss. 19-20), and 
sense that the award of land and land rights in terms of the Act will probably transfer either land ownership or limited real rights (mainly servitudes) to the labour tenant, the result is that the redistribution process in this case upholds the common-law tenure system. In fact, in the sense that the institution of labour tenancy itself is basically transformed into landownership, the diversity of land rights is actually diminished rather than extended or promoted

\subsection{Evaluation of redistribution policy}

Given the nature and the purpose of redistribution, it is to be expected that the major part of redistribution laws and programmes would be aimed at increasing the speedy and cheap delivery of land and access to land, both in the residential and the agricultural sectors. In this case, there is no question of restitution or restoration of previously lost land or land rights - the purpose is simply to change the current unequal distribution of land and of means to gain access to land by way of state intervention in the market process.

As far as redistribution of land is concerned, the intention and the declared policy objective is once again to make provision for a variety of flexible land rights, but the reality is that most of the redistribution initiatives tend to transfer commonlaw ownership of land to the beneficiaries or to promote the aspiration for acquisition of ownership. Even the initiatives that mention a variety of rights explicitly, like the Housing Act, tend to create frameworks that either leave the question of variety open or openly privilege full common-law ownership. Where there is a mention of other land rights, as in the case of the Labour Tenants Act, these rights tend to be limited real rights in the common-law mould, and they are nothing more than subsidiary rights that support or accompany the main right, which is ownership of land.

\section{Tenure reform policy and laws}

\subsection{Definition of tenure reform as a form of land reform}

Tenure reform is a process by which the land rights of people who do have land or access to land are strengthened and secured. The problem with many of these land rights is usually that they are insecure, either because of the way in which they have been acquired or vested or because of the discriminatory laws that applied to them in the past, and the aim is to provide either temporary or

proccedings before a court (s. 21). Apart from an order to transfer the affected land or a right in the affected land to the labour tenant, a court may also order that other land or rights in other land be transferred to the labour tenant, either as an alternative or in addition to the award of affected land (s. 22). If land or a nght in land is awarded, the landowner is entitled to just and equitable compensation(s. 23). Also see Du Plessis et al (1997b:538-540) 
permanent security of tenure. In other cases, the problem is that the rights in question are unsuitable for the purpose they serve, for example because they do not provide access to financing, or because they feature within a problematic tribal or group structure that might disadvantage women or other land users. 56

\subsection{Tenure reform laws}

The former National Party government's limited process of land reform included the promulgation of a couple of laws that served a tenure-reform purpose in that they increased the security of certain tenure arrangements. This usually proceeded no further than the so-called "upgrading" of certain tenure rights: occupation permits to leasehold, and leasehold to common-law ownership. The Conversion of Certain Rights into Leasehold or Ownership Act 81 of 1988 provided for the conversion of land permits into leasehold, and for the conversion of leasehold into ownership. 57 The Upgrading of Land Tenure Rights Act 112 of 1991, which was one of the laws promulgated as part of the previous National Party government's limited programme of land reforms introduced in 1991, had much the same effect in that it had the limited purpose of upgrading the precarious land rights that were granted to black people, during the apartheid era, with regard to state land (mostly of a residential nature and in urban areas) to full ownership. 58

The Development Facilitation Act 67 of 1995, which was discussed earlier for its redistributive effect (in that it facilitates and speeds up the delivery of land for housing), also has a tenure reform aspect to it. This aspect concerns the

56 See footnote 15 above, and compare the 1997 White Paper p. 60-69 on tenure-reform programmes. The land tenure-reform programme is now formally sanctioned and controlled by s. 25(6) of the 1996 Constitution. The "overlapping" of conflicting layers of land-use claims and rights was caused by forced removals and resettlements in already occupied areas during the apartheid era is a major source of insecurity of tenure in rural areas; see footnote 4 above.

57 See Du Plessis et al. (1997a:263) regarding the current status of the Act. See Mnisi v. Chauke and Others; Chauke v. Provincial Secretary, Transvaal, and Others 1994 (4) SA 715 (T) for an example of how these upgradings can go wrong. The widow of a man who held an occupation right to a residential property inherited the right, and had the right to occupy upgraded to leasehold and then-to ownership. She remarried, and then sold the property. The new owner wanted to evict the children of the previous owner and her deceased husband, the children claiming that the mother had no right to sell the property and leave them homeless Their claim is clearly untenable in terms of Western property law, but makes sense in terms of communal or traditional perceptions of land rights. The eviction succeeded and the counterclaim of the children to have the upgradings set aside was dismissed.

58 This Act was also involved in the Mnisi/Chauke case, see the previous footnote above. The Act was amended by the Upgrading of Land Tenure Rights Amendment Act 34 of 1996; see Du Plessis et al. (1997a:262-263) for a discussion. The amendments do not affect the general conclusions for present purposes. This law is destined to be repealed; see Anon. (1997:11-14). 
possibility of creating stronger and more suitable land rights for housing development, but since the land rights involved are either initial ownership59 (that is admittedly a suitable land right created for a specific land-reform purpose) or full ownership, this has little importance for present purposes.

The Land Reform (Labour Tenants) Act 3 of 199660 also has a tenure reform aspect besides its redistributive purpose. This consists in the provisions in Chapter 2 of the Act, aimed at securing the occupation right of a labour tenant. A person who was a labour tenant on 2 June 1995 has the right, together with his or her family members, to occupy and use that part of the farm that they were occupying and using on the said date and the occupation and use of which is restored to them in terms of the Act or of any other law. Such occupation may only be terminated in terms of the Act, either by waiver of the right, or by death, or upon eviction in terms of the Act, or upon the acquisition of ownership or other rights to land or compensation.61 The Act prescribes a procedure for the eviction of labour tenants and their families, and requires that such evictions take place in terms of a court order, following a specific application procedure, and it prescribes specific factors that have to be taken into account before the court can grant such an order. ${ }^{62} \mathrm{~A}$ labour tenant who is 65 years old or is unable to provide labour personally and has not nominated another person to do so may not be evicted at all. ${ }^{63}$ The Act also provides for the reinstatement of a person who would have had a right to occupy and use land if the Act was in force on 2 July 1995 and who vacated or was evicted between then and the commencement date of the Act. ${ }^{64}$ Chapter 2 of the Act therefore upholds and reinforces the position of labour tenants who do not acquire ownership in terms of Chapter 3 of the Act, or

59 S 62 of the Act; see footnote 42 and accompanying text above

60 As amended by the Land Restitution and Reform Laws Amendment Act 63 of 1997 (see fn. 52 above). The redistributive aspects of this Act were also considered in the previous section above

61 S. 3(1)-(2) The section also contains specific provisions with regard to succession in the place of a labour tenant who died or became unable to maintain the contract (both by family members and others) and waivers of the rights of a labour tenant. S. 4 provides for the provision of labour by a nominee of the labour tenant.

62 Ss. 5, 6, 7. S 7 provides that the eviction must be just and equitable, and the labour tenant must have either refused to provide labour or committed such a material breach of the agreement that it cannot be remedied S. 8 provides for the relocation of labour tenants in a situation where the farmer's operational needs justify it. Urgent evictions are possible in terms of $\mathrm{s} .15$.

63 S. 9. Upon the death of such a labour tenant his or her associates may be given 12 months' notice to vacate the farm.

6422 March 1996; Government Gazetre 17051 
of labour tenants who are still waiting to have their applications for ownership processed, by providing them with suitable security of tenure. This is an example of a land right that is secured and protected without upgrading it to or transforming it into landownership, and it illustrates the possibility to establish security of tenure without upgrading or transforming existing rights into ownership rights. The fact that the rights that exist in practice (and labour tenancy, like sharecropping, is a good example here) were often created to fulfil a specific need suggests that it may be best to keep those rights intact and simply bolster them by providing the required security of tenure and other requirements (like the possibility to give access to financing) by statute.

The Communal Property Associations Act 28 of 1996 is also an example of a land reform law that creates or secures an existing land right without doing so in terms of the ownership paradigm. This Act creates a statutory structure, vaguely reminiscent of the Sectional Titles Act 95 of 1986, within which members of a group or community can shape and hold their land rights communally, but with the advantages of security of tenure and open and democratic control. This Act simultaneously offers a framework within which land can be awarded to a group or community that was successful with a restitution or redistribution claim. 65 The Act creates a special legal person, called a communal property association, through which the members of the group exercise their property rights in the communally held land. A communal property association is registered, ${ }^{66}$ and it has to draft and register a constitution that complies with the provisions of the Act ${ }^{67}$ Certain principles with which the constitution has to comply are laid down in the Act, ${ }^{68}$ and for present purposes the most interesting principle is that all members shall have fair access to the property, and that members shall not be excluded unfairly from access to or the use of any part of the property that was allocated for the member's exclusive use or for common use, except in terms of the constitution. Procedures for decision-making, availability of information, conciliation, monitoring and inspection, approval for certain transactions

65 See s. 2. The Act applies to a community that was successful with a restitution claim, or that was successful with a redistribution application involving some sort of state support, or a community approved by the minister in terms of $s$ 2(2). Chapter 5 in Budlender et al. (1998) dealing with this Act contains no commentary

66 The main objective of the association is to hold property in common: s. $8(2)(b)$.

67 Ss. 5, 6, 7, 8. The constitution has to reflect the view of the majority of members of the association: s. $8(2)(f)(i 1)$

68 S. 9: the constitution must provide for fair and inclusive decision-making processes; equality of membership, democratic processes; fair access to the property of the association; accountability and transparency. 
regarding the property, administration, liquidation and deregistration of the association are set out in the Act (ss. 10,11, 12,13). The interesting thing is that the actual nature and content of the rights that a member of a property association acquires and holds are left open by the Act, and have to be determined in the constitution of the association. Generally speaking, these rights would accord roughly with the rights that a member of a tribal community acquires in a tribal land-rights system, but in this case the rights are formalised, democratic and open decision-making is ensured and discrimination (for instance against women) is precluded. One can say, therefore, that the Act creates a suitable land right for a specific need, and that the right so created is flexible, open for change and development with time and changing circumstances, but still secure. This Act embodies a clear choice for the creation and protection of land rights outside the common-law ownership framework.

The Interim Protection of Informal Land Rights Act 31 of 1996 provided temporary and transitional 69 protection to certain categories of informal or insecure land rights. ${ }^{70}$ The categories that were protected are: persons with the use or occupation of or access to land in terms of customary law, tribal custom or administrative practice of a certain community or area; the right in land of a beneficiary in terms of a trust established by legislation and where the trustee is in public office; ${ }^{71}$ persons who had beneficial occupation of land for a continuous period of at least five years prior to 31 December 1997;72 a person who has use or occupation of land that is similar to use or occupation that could have been upgraded in terms of the Upgrading of Land Tenure Rights Act 112 of 1991, without being formally recorded in the relevant register; rights and interests of tenants, labour tenants, sharecroppers and employees where those rights are purely contractual; and rights and interests based purely on temporary permission of the landowner and that are revocable at will. These rights were protected in that the holders could not be deprived of these rights other than in accordance

S. 5(2) provides that the Act shall lapse on 31 December 1997 unless the date is extended by the minister of land affairs, with the approval of parliament, for no more than 12 months. The validity of the Act was subsequently extended to 31 December 1998; see Anon (1997:15-16). Chapter 6 in Budlender ef al. (1998) that deals with this Act contains no commentary. A permanent act is currently being drafted to replace the interim Act, but no information was available at the time of writing. I assume that the permanent act will follow roughly the same pattem as the interim Act.

70 See Du Plessis et al. (1997a:259) for an overview.

71 In the apartheid era the practice was established that land would be held in trust by a minister or the president for a tribe or community.

72 Beneficial occupation is defined as holding the land as if one were the owner, without force openly and without permission of the registered owner: $s$. $1(1)(i)$. 
with the provisions of the Act, but no rights were created or conferred by the Act (s. 1(2)). The way in which the Act simply upheld and reinforced weak or insecure existing rights is promising for present purposes, but given the temporary nature of the protection the Act loses some significance for this analysis. The fact that the rights in question were protected by simply upholding and reinforcing them against unjust evictions is nevertheless significant. This Act, like some of the other tenure reform laws, bolstered and protected insecure land rights by lifting them above the threshold of security demanded by the very notion of land reform and by the spirit of the property clause in the 1996 Constitution. This was done through the use of statutory anti-eviction and due-process provisions, and the whole process was implemented outside of (and to a large degree contrary to) the traditional ownership paradigm.

The Extension of Security of Tenure Act 62 of 1997 is the latest major piece of tenure reform legislation, and it follows the same strategy of bolstering insecure rights by way of statutory anti-eviction and due-process provisions. The Act is basically intended to provide security of tenure for farm labourers that do not benefit from the protection of the Land Reform (Labour Tenants) Act 3 of 1996 because they do not qualify as labour tenants. The focus is on "occupiers" of land, defined ${ }^{73}$ as a person residing on land which belongs to another person, and who has on 4 February 1997 or thereafter had 74 consent or another right in law to do so. ${ }^{75}$ The Act provides security of tenure for occupiers of land in that consent to occupy land may not be terminated other than in accordance with the Act (s. 3 ); there is provision for the facilitation of long-term security of tenure by way of subsidies for on-site and off-site developments where the occupiers can acquire either ownership or other land rights in the development (s. 4), the Act sets out and delimits the rights and duties of landowners and occupiers, specifically with

73 S. 1(x). Du Plessis et al. (1997b:540 ff) discuss the Bill. Also see Anon. (1997:9-10). In Karabo v. Kok 1998 (4) SA 1015 (LCC) the Land Claims Court confirmed that the Act has to be applied strictly to ensure that the beneficiaries enjoy the intended protection: no eviction is to be allowed unless the requirements of the Act are complied with. Also see Atkinson v. Van Wyk and Another 1999 (1) SA 1080 (LCC)

74 As in the case of the Labour Tenants Act, the retroactive provisions are meant to preclude or deal with anticipatory evictions carried out during the drafting, discussion and promulgation of the Act.

75 The definition in $\mathbf{s}$. $\mathbf{l}(\mathbf{x})$ excludes labour tenants, persons using or intending to use the land mainly for industrial, mining, commercial or commercial farming (but including a person who works the land herself and does not employ anybody who is not a family member), and a person with an income in excess of the specified amount (in terms of regulations). The Act does not apply to land in a township, except if that land is designated for agricultural use: s. 2 
regard to security of tenure (s. 6); rights of residence may only be terminated 76 and evictions may only be undertaken in terms of the Act. ${ }^{77}$ An interesting feature is that the Act makes special provision for dispute resolution procedures, including mediation and arbitration, before a dispute lands in court (Chap. 5). The main characteristic of the Act is that it does not change the nature of the land rights enjoyed by occupiers; it simply secures those rights against arbitrary and unfair evictions. The nature of the occupier's right is, therefore, retained but simultaneously reinforced by statute. This is once again a policy choice in favour of the retention of a variety of land rights, even with regard to the same piece of land.

The latest tenure-reform law concerns the position of people who occupy land unlawfully. The Prevention of Illegal Eviction from and Unlawful Occupation of Land Act 19 of 1998,78 which was rather surprisingly introduced by the ministry of housing and not the ministry of land affairs, repeals the Prevention of Illegal Squatting Act 52 of 1951, which was one of the most hated and draconian apartheid land laws, and replaces it with more reasonable and fair prevention and eviction procedures. The Act prohibits the receipt or solicitation of consideration for unlawful occupation of land (a major problem in many areas) (s. 3); provides a procedure for the eviction of people who have occupied land unlawfully for a year or longer, ${ }^{79}$ as well as a procedure for urgent evictions (s. 5); and provides for evictions at the instance of state organs (s. 6). The Act does not propose to

76 S. 8 A right of residence may only be terminated if it is just and equitable. Factors to be taken into account are the faimess of any agreement between the parties, their conduct, their interests, hardship caused for either of them if the right should be terminated or upheld, and the faimess of the procedure followed in terminating the right. Special provision is made for occupiers whose right of residence arises solely from an employment agreement (s. 8(2)) and for occupiers who have resided on the land for at least 10 years and have reached the age of 60 or have become unable to supply labour to the owner in person (s. 8(4))

77 Ss. 9-10 provide that an eviction may only take place with the authority of a court order, which can be granted after a specified procedure has been followed. S. 10 makes a distinction between occupiers before and after 4 February 1997, the former category being protected more strictly and the latter being more dependent upon the agreement between landowner and occupier. Ss. 11 and 12 provide for the effects and practical implementation of an eviction, and s. 15 for urgent evictions. S. 14 makes provision for the restoration and payment of damages in case of unlawful evictions.

78 Government Gazette 18964 1998-06-05.

79 S. 4. The major feature of the section is that a court order is required for the eviction, in accordance with s. 26(1) of the 1996 Constitution. In the case of large groups the court has to consider whether alternative land for settlement has been made available by the local authority or can be made available. 
Property rights and hierarchies of power: a critical evaluation of land-reform pollcy in SA

create any land rights; it simply provides fair procedures for the eviction of unlawful occupants.

\subsection{Evaluation of tenure-reform policy}

As was pointed out earlier, the purpose with tenure reform is neither to restore land rights nor to grant or improve access to land - the aim is to transform the law in order to improve the security of tenure and the value of previously disregarded and unprotected land rights. It is therefore to be expected that tenure-reform laws would be of great interest for the purposes of the current policy analysis, since they hold the greatest potential for the transformation of the existing structure of the land rights system.

The conclusion with regard to tenure-reform laws is mixed. Some (and particularly early) tenure reforms simply upgrade existing land rights to ownership, while others create new land rights for specific needs and support them with the necessary security of tenure, access to financing and so on; or alternatively reinforce existing weak land rights by providing statutory security of tenure. This usually assumes the form of a prohibition against and strict control of evictions. Interestingly enough, no tenure reforms have been introduced yet to extend this process to urban properties in the form of rent-control laws. The tenure-reform (and overall land reform) laws that embody the strongest evidence of a policy choice in favour of a variety of land rights are the Communal Property Associations Act and the Extension of Security of Tenure Act. These acts provide security of tenure not by translating insecure rights into rights that occupy a stronger position in the traditional hierarchy of property rights, but by lifting them (through the use of statutory anti-eviction and due-process provisions) above the threshold of minimum security of tenure that is required in terms of the ideal of land reform, thereby protecting and reinforcing them in their own right instead of in terms of the ownership paradigm. This brings about significant benefits in the form of raising undervalued land rights above the threshold of minimum recognition and protection, but it also brings about significant changes in the existing distribution of land rights in that certain due-process restrictions are imposed on the previously unrestricted rights of (mainly white) landowners to retract existing privileges or rights and evict (mainly black) occupants with impunity. The most significant changes in this regard are brought about by laws that provide substantive protection, in more or less absolute terms, for the occupation rights of the very young, the elderly and the weak. In certain circumstances occupiers in these categories may not be evicted at all, or only if alternative accommodation is available. This amounts to a real redistribution of property and of power, because it brings about significant restrictions on the rights of property owners. 


\section{Evaluation and concluding remarks}

From the analysis above it may be concluded that most of the early land-reform efforts, and especially those that were introduced by the former National Party government in 1991, did not succeed in breaking down the structural and dogmatic privilege of the common-law ownership paradigm at all; they simply restored or awarded ownership or upgraded other existing rights to ownership if at all possible. The same result is reached by some of the later reform laws, even if the intention to create greater diversity and variety of rights is often declared as a policy choice. Once again, reforms that remain within the ownership paradigm are limited in their overall efficacy in that they do not help to break down the structural hierarchy within which the present imbalance of land rights was created and upheld. At least in a philosophical and theoretical perspective, this must be evaluated as a shortcoming in the land-reform process. In terms of the theoretical framework set out in the introductory sections of the article, these reforms do not succeed in the transformative task of restructuring the basic framework within which the current distribution of property, wealth and power is justified and entrenched.

On the whole, the land reform laws do not fare at all badly as far as breaking out of the common-law ownership mould is concerned: some of the reform laws do succeed in creating suitable, needs-driven land rights. The Housing Act states the intention to promote greater variety in land rights without providing hard evidence of implementing or creating rights of that nature, but at least it states this policy option clearly and leave the option open for future development. The Restitution of Land Rights Act is applied, at least when it concerns the land rights of groups and communities, within an alternative framework (the Communal Property Associations Act) that makes explicit provision for the creation and development of new, suitable land rights that do not fit into the ownership paradigm and do not depend on it for their value, their legitimacy or their protection.

Apart from these partially successful reforms there are a number of reform laws that succeed in breaking even more clearly with the ownership paradigm. Of these, the Communal Property Associations Act and the Extension of Security of Tenure Act have to be singled out. They promote the aims of land reform and security of tenure outside of the ownership paradigm in terms of one of two strategies: (a) the Communal Property Associations Act creates new land rights to suit specific needs that do not depend on or fit into the ownership paradigm; while (b) the Extension of Security of Tenure Act provides statutory reinforcement, in the way of anti-eviction and due-process provisions, for weak and insecure rights. Both strategies succeed in bypassing the ownership paradigm, thereby ensuring that the rights that are created or reinforced acquire their value and protection on their own terms, without reference to the traditional hierarchy of stronger and weaker property rights. 
The Communal Property Association Act creates a completely open-ended and flexible statutory framework within which existing land rights and land use patterns can be reinforced by eliminating negative factors (undemocratic decisionmaking, arbitrary procedures, discrimination) but retaining and reinforcing positive factors (communal and social framework for land rights), while muchneeded security of tenure is ensured at the same time. This is a significant creation of the legislature, and the most remarkable feature is perhaps the fact that the statutory framework ensures that fundamental principles and procedures are maintained (much like the Sectional Titles Act does for sectional title ownership), but (and this is different from the Sectional Titles Act) without specifying and spelling out the exact nature and content of the rights involved - that is left to the constitution of each association to determine democratically. The Extension of Security of Tenure Act introduces an equally important innovation by pushing existing but weak or insecure land rights over the legal threshold to ensure that they offer the minimum security of tenure that is demanded by the concept of land reform, without changing the nature of the rights involved and without attempting to force them into the ownership paradigm. In this way, both the general notion of land reform and the constitutional value of creating and protecting secure and just land rights are served simultaneously, outside of the traditional (and now unsuitable) hierarchy of power that underlies the ownership paradigm.

Of course, the proof of the pudding is in the eating, and it remains to be seen what the real impact of these innovations on the existing distribution of land and wealth will be. The Department of Land Affairs deserves some credit for the innovation and creativity that was mustered to produce these laws in a relatively short period. What remains is to consider the alternatives and the implications.

As far as alternatives are concerned, the question is whether it would have been possible to go much further in moving away from the common-law ownership paradigm and towards the creation of new, needs-driven rights that do not fit into this paradigm. I can think of only a few cases where the matter could have been approached differently. The Restitution of Land Rights Act is still extremely ownership-oriented, but in view of restitution expectations and aspirations that may well be inevitable. People want land back, not limited or restricted or fanciful rights in land, and in all but the most exceptional cases 80 the ownershiporientation is perhaps justified. Furthermore, it is becoming increasingly clear that both the restitution process and the redistribution process will, when the circumstances permit and justify such a direction, rely on tenure-reform initiatives

80 Such as the restitution case Ex parte North Central and South Central Metropolitan Substructure Councils of the Durban Metropolitan Area and Another 1998 (1) SA 78 (LCC) discussed in footnote 26 above, where a settlement agreement provided that some claimants would receive specific rights or benefits instead of land 
(such as the Communal Property Associations Act 28 of 1996) to restore or redistribute suitable and needs-driven land rights instead of simply land or landownership. Ultimately, therefore, the question should be whether tenurereform laws are innovative enough and creative enough in this regard. The two most obvious criticisms that I can think of in this regard concern the redistributory aspect of the Labour Tenants Act and the protection of weak and insecure "lesser" land rights.

The redistributory aspect of the Labour Tenants Act could have been approached differently. The tenure reform aspect of this Act breaks down the ownership paradigm in that it upholds and reinforces labour tenancy as a strong, secure and unique land right, and possibly the redistributory aspect could have followed the same route. On the other hand, the purpose of the redistributory aspect was probably to use the opportunity to spread the distribution of landownership in the agricultural sector more equitably, and in that sense it is perhaps a necessary step despite its structural implications.

The protection of weak and insecure "lesser" land rights is probably not complete yet, especially in view of the fact that many of the informal rights that enjoyed the interim protection of the Interim Protection of Informal Land Rights Act have not yet been secured permanently. Another pressing need is probably the security of short-term tenancies, especially in the residential market, in urban areas where there is a pressing housing shortage, and among the financially weaker parts of the community. Some of these problems may yet be addressed by future legislation, and it will be interesting to see what policy direction is taken in protecting these rights.

The implications of the policy choices discussed in this article are complex and varied. On the one hand, the question may be asked whether it is really such a good idea to break down the common-law ownership paradigm, and whether that may not have negative economic effects, especially in the production and development of housing stock. On the other hand, it can also be asked whether a policy choice in favour of ownership or in favour of non-ownership land rights would have a positive or a negative effect on the potential tax base of federal, provincial and local government. The provision of strong statutory protection of non-ownership land rights even has hotly contested implications for the (interventionist or laissez-faire) style of government in general, and although I am not sure that the new South African government has taken a clear position on this issue yet, the philosophical and ideological roots of the post-apartheid South African society probably have a natural inclination towards the interventionist option, which offers better opportunities for protecting and advancing the weak and creating the climate for the achievement of equality, human dignity and freedom. In the final analysis, the main question remains: do the land-reform laws succeed in breaking down or undermining the existing hierarchies of power to 
such an extent that an effective and real redistribution of property, wealth and power becomes possible? To the extent that some land-reform laws succeed in opening access to land to all persons and in lifting all rights and interests in land above the threshold of minimum legal recognition and protection, and in creating real and effective checks and restrictions on the rights of current land holders, the answer must be in the affirmative. However, I have my doubts about the actual effect of the land-reform programme in undermining the hegemony of civil-law property rights and the power hierarchies inherent in traditional propertydistribution patterns. A more detailed analysis is perhaps required to determine whether the land reforms have had (or could have) sufficient impact on existing background law to remove the superficial impression that land reform amounts, on the one hand, to the almost inevitable restoration or proper protection of some fairly obvious deserving cases (the Restitution of Land Rights Act and the Communal Property Associations Act) and, on the other hand, the establishment of a due-process holding pattern (the Labour Tenants Act and the Extension of Security of Tenure Act), rather than a really redistributive intervention. Of these two tendencies, the creation of a strong due-process context within which even weak rights and interests are protected against arbitrary dispossessions and evictions is perhaps most significant, but in the final analysis one has to conclude that none of the relevant laws create new rights - they merely "freeze" existing rights (and, it has to be conceded, interests that amount to less than rights) until the law has taken its due course. There are only a very small number of exceptions, such as the absolute, substantive protection against any eviction of the very young, the elderly and the weak in the Extension of Security of Tenure Act. These few exceptions, it must be emphasised, do create real examples of land reforms that undermine the existing distribution of property and power and create a justifiable and equitable redistribution. The question is: is this enough? Does it establish a break with tradition and an amendment of the "background law" that is substantial enough to claim that we are transforming property law and property relationships? Are we simply rearranging the distribution of poverty and wealth and power, or are we actually addressing the inequalities in the distributive pattern? Are we restructuring property law, or are we simply adapting property law?

I cannot answer these difficult questions, but I am sure that an analysis like this will assist us in reflecting on the policy direction we want to and should take, determining the policy choices that are embodied in or reflected by the laws we make, and focusing on ways to eliminate or reduce the inconsistencies and inefficiencies we may identify in the process. There is no reason for complacency, and much to worry about. 


\section{Bibliography}

AFRICAN NATIONAL CONGRESS. 1994. The reconstruction and development programme: A policy framework. Johannesburg : Umanyano Publications for the ANC.

ALEXANDER, G.S. 1997. Commodity and propriety: Competing visions of property in American legal thought 1776-1970. Chicago : University of Chicago Press.

ANON. 1997. The Upgrading of Land Tenure Act. Land Info, 4(6):11-14, Oct./Nov./Dec

BRUDNER, A. 1995. The unity of the common law: Studies in Hegelian jurisprudence Berkeley : University of California Press.

BUDLENDER, G., LATSKY, J. \& ROUX, T 1998. Juta's new land law. Kenwyn : Juta

COHEN, F.S. 1935. Transcendental nonsense and the functional approach Columbia Law Review, 35:809-849.

COHEN, F.S. 1937. The problem of a functionalist jurisprudence Modern Law Review. 5-26.

COHEN, M R. 1927. Property and sovereignty. Cornell Law Quarterly, 13:8-30

COWEN, D.V. 1984. New patterns of landownership. The transformation of the concept of landownership as plena in re potestas. Johannesburg : University of the Witwatersrand Law Students' Association

CROSS, C. \& HAINES, R. 1988. Towards freehold? Options for land and development in South Africa's black rural areas. Cape Town : Juta

DE KLERK, M., ed 1991. A harvest of discontent: The land question in South Africa. Cape Town : IDASA.

DU PLESSIS, W, OLIVIER, N. \& PIENAAR, J. 1997a. Land reform gathers momentum during 1996. South African Public Law, 12:251-273.

DU PLESSIS, W , OLIVIER, N. \& PIENAAR, J. 1997b. Land reform continues during 1997 South African Public Law, 12:531-550.

GREY, T.C. 1989. Holmes and legal pragmatism. Stanford Law Review, 41:787-863.

HALE, R.L. 1923. Coercion and distribution in a supposedly non-coercive state. Political Science Quarterly, 38:470-494.

HOHFELD, W.N. 1913. Some fundamental legal conceptions as applied in judicial reasoning. Yale Law Journal, 23:16-59.

HOHFELD, W.N. 1917. Fundamental legal conceptions as applied in legal reasoning. Yale Law Journal, 26:710-770.

HOLMES, O.W. 1897. The path of the law. Harvard Law Review, 10:457-478.

HORWITZ, M.J. 1992. The transformation of American law, 1870-1960. New York : Oxford University Press

JAICHAND, V. 1997. The restitution of land rights: A workbook. Johannesburg : Lex Patria.

KLARE, K.E. 1994. Legal theory and democratic reconstruction: Reflections on 1989. (In Alexander, G.S. \& Skapska, G. eds. A fourth way? Privatization, property, and the emergence of new market economies. New York : Routledge. p. 310-333.)

LATSKY, J. 1998. The Development Facilitation Act. (In Budlender, G., Latsky, J. \& Roux, T. Juta's new land law. Kenwyn : Juta. Chap. 2.)

PIENAAR, J.M. 1997 Land reform, labour tenants and the application of the Land Reform (Labour Tenants) Act 3 of 1996. Journal of South African Law: 538-548.

REICH, C.A. 1964. The new property. Yale Law Journal, 73:733-787.

REPUBLIC OF SOUTH AFRICA. 1991. White Paper on Land Reform Pretoria : Government Printer.

REPUBLIC OF SOUTH AFRICA (State President's Office). 1994. White Paper on Reconstruction and Development. Pretoria : Government Printer

REPUBLIC OF SOUTH AFRICA (Department of Housing). 1994. White Paper: A National Housing Policy and Strategy for South Africa. GN 1376. Government Gazette 16178 of 23-12-1994. 
REPUBLIC OF SOUTH AFRICA (Department of Land Affairs). 1997. White Paper on South African Land Policy. Pretoria : Government Printer.

ROUX, T. 1998. The Restitution of Land Rights Act. (In Budlender, G., Latsky, J. \& Roux, T Juta's new land law Kenwyn : Juta. Chap. 3.)

SIMON, W.H. 1985. The invention and reinvention of welfare rights. Maryland Law Review, 44:1-37.

SIMON, W.H. 1986. Rights and redistribution in the welfare system. Stanford Low Review, 38:1431-1516.

SIMON, W.H. 1991. Social-republican property. University of California at Los Angeles Low Review, 38:1335-1413

SINGER, J.W. 1988. Legal Realism now. California Law Review, 76:467-544

VAN DER WALT, A.J. 1990. Towards the development of post-apartheid land law: An exploratory survey. De Jure 1-45.

VAN DER WALT, A.J. 199la. Introduction. (In Van der Walt, A.J., ed. Land reform and the future of landownership in South Africa. Cape Town : Juta. p. 1-7.)

VAN DER WALT, A.J. 1991b. The future of common-law landownership. (In Van der Walt, A J., ed. Land reform and the future of landownership in South Africa. Cape Town : Juta p 21-35.)

VAN DER WALT, A.J. 1992. The fragmentation of land rights. South African Journal on Human Rights, 8:431-450

VAN DER WALT, A.J. 1993. Ownership and personal freedom: Subjectivism in Bernhard Windscheid's theory of ownership. Tydskrif vir Hedendaagse Romeins-Hollandse Reg, 56 569-589.

VAN DER WALT, A.J. 1995. Towards a theory of rights in property: Exploratory observations on the paradigm of post-apartheid property law. South African Public Law, 10:298-345.

WEINRIB, E J. 1995. The idea of private law. London : Harvard University Press

WILLIAMS, L A. 1998. Welfare and legal entitlements: The social roots of poverty. (In Kairys, D., ed. The politics of law: A progressive critique. 3rd ed. New York : Basic Books. p. 569-590.)

WILSON, F. \& RAMPHELE, M. 1989. Uprooting poverty: The South African challenge Cape Town : David Philip 